\title{
ON INTERPRETING SECURITY RETURNS DURING THE EX-DIVIDEND PERIOD*
}

\author{
Kenneth M. EADES \\ University of Michigan, Ann Arbor, MI 48109. USA \\ Patrick J. HESS \\ Ohio State Universitv, Columbus, OH 43210, USA \\ E. Han KIM \\ University of Michigan, Ann Arbor, MI 48109, US.4
}

Received December 1982, final version received September 1983

In this paper we examine the ex-dividend day returns of several taxable and non-taxable distributions. The ex-dividend day returns for the taxable common stocks are consistent with the hypothesis that dividends are taxed more heavily than capital gains. However, the ex-dividend day returns of preferred stocks suggest that preferred dividends are taxed at a lower rate than capital gains: non-taxable stock dividends and splits are priced on ex-dividend days as if they are fully taxable; and non-taxable cash distributions are priced as if investors receive a tax rebate with them. We also find that each of these distributions exhibits abnormal return behavior for several days surrounding the ex-dividend day. We investigate several possible cxplanations for this anomaly, but none is capable of explaining the phenomenon.

\section{Introduction}

Campbell and Beranek (1955) note that the ex-dividend behavior of stock prices influences the portfolio decisions of investors. In particular, they observe that if the prices of shares fall by the full amount of dividends, taxable investors will, at the margin, accelerate their sales before ex-dividend days and delay their purchases until after ex-dividend days. These authors and a follow up study by Durand and May (1960) find that, on average, ex-day stock prices

\footnotetext{
*We have bencfited from comments by participants at the July, 1983 NBER Tax Conference, and finance workshops at Ohio State University, University of Chicago and University of Michigan. In addition, we would like to thank P. Asquith, W. Beranek, F. Black. J. Brickley, G. Constantinides, D. Diamond, R. Holthausen, S. Kon, and T. Stober, and especially Merton Miller, Myron Scholes, Clifford Smith, and R. Watts, the referee for this Journal. We are also grateful to Compuserve of Columbus, Ohio for making available to us a significant portion of the data used in this study. This research was supported by summer research grants from The University of Michigan Graduate School of Business Administration and The Ohio State University College of Administrative Science.
} 
fall by less than the amount of dividends paid. Elton and Gruber (1970) expand the reasoning of Campbell and Beranek (1955) to estimate the marginal stockholder's tax rate on dividends from the average ex-dividend day price drop. Like the earlier studies, Elton and Gruber find that stock prices fall by less than dividends per share, and conclude that dividend-related tax effects are at work in the pricing of common stocks. Kalay (1982) refines the Elton and Gruber study and reaches a similar conclusion. ${ }^{1}$

This paper repeats the 'ex-dividend day experiment' with a variety of samples. Using a somewhat different methodology we confirm the prior results with a sample of taxable distributions to common stocks. We next perform the ex-dividend day experiment with taxable distributions to preferred stocks, non-taxable cash distributions to common stocks, and stock dividends and splits. These results are quite surprising and cast doubt upon the tax interpretation of ex-day pricing behavior. The taxable preferred stock dividends are priced as if dividends are taxed at a lower rate than capital gains, non-taxable stock dividends and splits are priced on ex-dividend days as if they are taxable, while non-taxable cash distributions are priced as if they impose negative taxes on the recipients.

We also examine the pricing behavior for five days on each side of the ex-dividend day which we define as the "ex-dividend period'. ${ }^{2}$ Like our other samples, the ex-dividend period is a control sample for the 'ex-dividend day experiment'. If the experiment is unable to distinguish ex-days from surrounding days, further doubt is cast upon the tax interpretation of ex-day pricing behavior. We find that abnormal returns are neither confined to the exdividend day, nor are they confined to taxable distributions by common stocks. Indeed, all samples reveal anomalous return behavior during the ex-dividend period. Taken together, these experimental repetitions suggest that the tax interpretation, at least in its simplest form, is inconsistent with the results of the 'ex-dividend day experiment'.

We consider several explanations of the ex-dividend period anomaly. In particular, we examine the possibility of errors in our data, the influence of the day of the week effect, dividend announcement effects, infrequent trading of securities, and non-normality of securities' rates of return. None of these possibilities is capable of explaining the ex-dividend period results.

\footnotetext{
${ }^{1}$ Other researchers have followed a different line of reasoning in investigating the tax impacts of dividends. Black and Scholes (1974), Long (1978), Litzenberger and Ramaswamy (1979, 1980), Hess $(1982,1983)$ and Miller and Scholes (1982) test for tax parameters in equilibrium pricing models which allow for differential taxation of dividends, interest and capital gains. In contrast to the unanimity of conclusion reached with the ex-dividend day studies, these authors have reached conflicting conclusions.

${ }^{2}$ This investigation is motivated by the Black and Scholes (1973) finding that common stocks exhibit abnormal return behavior for several days surrounding the ex-dividend days of taxable dividends
} 
In the next section we present a statement of the differential tax hypothesis, present our methodology and report our ex-dividend day results. Section 3 extends our analysis to the ex-dividend period, and section 4 examines several plausible explanations for the ex-dividend period anomaly. The final section summarizes our results and conclusions.

\section{Ex-dividend day returns}

\subsection{The model}

Elton and Gruber, and Kalay estimate the tax impacts of dividends by observing the ex-dividend day behavior of common stock prices. Because investors who receive dividends must pay taxes due on the dividends, these authors reason that the market will value a dollar of dividends less than a dollar of capital gains; therefore, the ex-day prices of stocks will on average fall by less than the amount of the taxable dividend. To formalize this reasoning, we define the after-tax rate of return on security $i$ as

$$
\tilde{R}_{i, t}^{\tau} \equiv \frac{\tilde{P}_{i, t}-P_{i, t-1}}{P_{i, t-1}}\left(1-\tau_{\mathrm{g}}\right)+\frac{D_{i, t}}{P_{i, t-1}}\left(1-\tau_{\mathrm{d}}\right),
$$

where $\tilde{R}_{i, t}^{\tau}$ is the after-tax rate of return on day $t$ to the marginal investor in security $i, \tilde{P}_{i, t}$ is the price of security $i$ at the end of day $t, \tau_{\mathrm{g}}$ is the present value of the capital gains tax rate for the marginal investor, $D_{i, t}$ is the dividend paid on day $t$, and $\tau_{\mathrm{d}}$ is the marginal investor's tax rate on dividend income. Taking expectations of eq. (1) and rearranging terms we obtain

$$
\mathrm{E}\left(\tilde{R}_{i, t}^{\tau}\right)=\mathrm{E}\left(\tilde{R}_{i, t}\right)\left(1-\tau_{\mathrm{g}}\right)-\frac{D_{i, t}}{P_{i, t} 1}\left(\tau_{\mathrm{d}}-\tau_{\mathrm{g}}\right),
$$

where

$$
\mathrm{E}\left(\tilde{R}_{i, t}\right)=\frac{\mathrm{E}\left(\tilde{P}_{i, t}\right)-P_{i, t-1}+D_{i, t}}{P_{i, t-1}}
$$

is the expected pre-tax rate of return on day $t$ for security $i$. If expected after-tax rates of return are constant over time $\left[\mathrm{E}\left(\tilde{R}_{i, t}^{\tau}\right)=\mathrm{E}\left(\tilde{R}_{i}^{\tau}\right)\right.$ for all $\left.t\right]$ eq. (2) can be rewritten as

$$
\mathrm{E}\left(\tilde{R}_{i, t}\right)=\gamma_{0, i}+\gamma_{1, i} d_{i, t}, \quad i=1,2, \ldots, N, \quad t=1,2, \ldots, T .
$$

where

$$
\gamma_{0, i} \equiv \frac{\mathrm{E}\left(\tilde{R}_{i, t}^{\tau}\right)}{1-\tau_{\mathrm{g}}}, \quad \gamma_{1, i} \equiv \frac{\tau_{\mathrm{d}}-\tau_{\mathrm{g}}}{1-\tau_{\mathrm{g}}}, \quad d_{i, t} \equiv \frac{D_{i, t}}{P_{i, t-1}} .
$$

Eq. (3) captures the essence of the tax hypothesis in its simplest form: because 
dividend yields $\left(d_{i, t}\right)$ are zero on all days except the ex-day, the tax effects of dividends will only be reflected in the ex-day returns. If the marginal investor's tax rate on dividend income is greater than the present value of the capital gains tax rate $\left(\gamma_{1, i}>0\right)$, the investor will demand a tax premium in the form of a higher pre-tax return on the ex-dividend day. Consequently, the expected pre-tax rate of return from holding a security going ex is equal to its non ex-day expected rate of return $\left(\gamma_{0, i}\right)$ plus a tax premium $\left(\gamma_{1 . i} d_{i, t}\right)$.

\subsection{Transaction costs}

In deriving eq. (3), we have implicitly assumed that securities are priced as if transaction costs are zero. However, this assumption precludes the existence of any differential ex-day tax effect in security returns. ${ }^{3}$ Within limits, investors may use short-term losses on capital assets to offset ordinary income (dividend income), ${ }^{4}$ and up to these limitations individual investors are tax neutral between dividends and capital gains. In addition, security dealers are allowed to designate capital assets as inventory holdings and thereby totally escape any limitations on the use of short-term losses as an offset against taxable income. These provisions of the tax code along with zero transaction costs are sufficient to ensure that short-term investors and security dealers will arbitrage away any differential tax effects on dividends and capital gains. In short, zero transaction costs rule out any dividend-related tax effects and ensure that $\gamma_{1, i}$ equals zero for all $i$.

With positive transaction costs, there may exist an ex-dividend day tax premium, but the magnitude of the premium will be bounded from above by the marginal costs of short-term traders. We assume that on any trading day there is a group of investors who intend to make trades for portfolio reasons and are indifferent among securities that they regard as perfect substitutes. For these portfolio traders the marginal costs of tax trading are zero. Thus, among securities which they regard as perfect substitutes, they will choose the security that maximizes their after-tax-risk-adjusted return. It follows from eq. (3) that the marginal portfolio traders will demand a positive tax premium if they are subject to differential tax rates between dividends and capital gains. However, tax-arbitrage capital will be supplied by short-term traders provided that the ex-day tax premium covers their marginal transaction costs; thus, these costs become the upper bound on the ex-day tax premium.

These arguments suggest that the marginal transaction cost of short-term traders plays an important role in the ex-day return behavior of securities. Although it is difficult to identify the effective costs of trading for short-term

\footnotetext{
${ }^{3}$ This issue is also discussed by Kalay (1982) and Miller and Scholes (1982).

${ }^{4}$ Prior to 1977 only the first $\$ 1,000$ of short-term capital losses could be used to offset ordinary income (dividend income). The current limitation is $\$ 3,000$.
} 
traders, the introduction of negotiated commissions enables us to date a change in the nominal costs of trading. Prior to May 1, 1975 commission rates were fixed, and the nominal round-trip costs to short-term traders was $2 \%$; although the existence of third and fourth markets suggests that the effective costs were much less than 2\%. Since May 1, 1975 commissions have been negotiated, and the nominal costs of trading, particularly for large transactions, have fallen significantly. Because of this intertemporal change, it seems reasonable to check for changes in the ex-day tax effects between pre- and post-negotiated commission periods. ${ }^{5}$

\subsection{Test statistics}

Eq. (3) may be used to infer several testable implications; the most obvious being that ex-day returns include a tax premium. Our interest here is limited to investigating the often cited evidence of an ex-day tax premium; and consequently, we focus on ex-day returns and ignore the more elaborate implications of (3). ${ }^{6}$ In this sense our work closely parallels that of Elton and Gruber, and Kalay. These authors calculate the ratio of ex-day share price changes to dividends per share. Unfortunately, these ratios are not easily aggregated across securities or across time.

Two obvious problems of the price change-to-dividend ratio are heteroscedasticity and lack of independence. The heteroscedasticity problem arises because the price changes are being scaled by dividends which are unequal across securities. For instance, if two firms have equal variance of price changes but one firm has $\$ 1.00$ dividend and the other has a $\$ 0.10$ dividend, the variance of the price ratio of the $\$ 1.00$ dividend firm is only one percent of the variance of the price ratio of the $\$ 0.10$ dividend firm. The result is that the simple average of the two price ratios assigns far too much weight to the low dividend security. The difficulty of interpreting these price ratio averages is further exacerbated by the lack of independence of price changes across securities with the same ex-day. ${ }^{7}$

\footnotetext{
${ }^{5}$ It is tempting to argue that members of the stock exchange face transaction costswhich are low enough to allow them to engage in unrestricted tax arbitrage. This ignores the opportunity costs of their transaction. For example, if members face a binding constraint on the number of profitable trades they may undertake at any given point in time, any tax trades would necessitate foregoing some other profitable trades. These foregone profits would represent the marginal transaction costs for the members of the exchanges. See Phillips and Smith (1980) for a related discussion on the opportunity cost of the use of seats on the exchanges.

${ }^{6} \mathrm{Hess}(1983)$ tests restrictions on the coefficients of model similar to (3).

${ }^{7}$ If the covariance matrix of the disturbance terms were known or estimable, both of these problems could be avoided by computing a GLS version of the Elton and Gruber ratic. How:. ir, the covariances are unknown and estimation for a sample as large as ours is computationally infeasible.
} 
To avoid these problems we form a portfolio by equally weighting all stocks that go ex-dividend on each trading day. Because the composition of these ex-day portfolios changes over time, we standardize the portfolio returns as

$$
S E R_{t}=\left(R P_{t}-\overline{R P}\right) / \hat{\sigma}_{t}
$$

where $R P_{t}$ is the ex-day portfolio return on day $t, \overline{R P}_{t}$ is the estimated mean portfolio return and $\hat{\sigma}_{t}$ is the estimated standard deviation of portfolio returns. The portfolios' means and standard deviations are estimated using the portfolio returns for the period beginning 30 days before and ending 30 days after the ex-day, a total of 60 observations excluding the ex-day. ${ }^{8}$ Thus, $\overline{R P}$ estimates the non ex-day expected rate of return $\left[\gamma_{0}\right.$ in eq. (3)] for the portfolio of securities that go ex-dividend on day $t$, and $S E R_{t}$ measures the standardized tax premium $\left[\gamma_{1} d\right.$ in eq. (3)] for the ex-day portfolio.

Assuming that security returns are independently and identically distributed over time as multivariate normal, each of the standardized excess returns $(S E R)$ of (4) has a univariate student $t$ distribution with fifty nine degrees of freedom and a standard deviation of one. Under the null hypothesis of no ex-day tax premium, each of the SER's has a mean of zero. The asymptotic distribution of the average $S E R$ is normal with a standard deviation equal to the square root of the inverse of the number of observations $\left(T^{-1 / 2}\right)$. Conditional on the null hypothesis of no tax effect, the mean of the asymptotic distribution is zero.

\subsection{A problem of interpreting results}

Our basic sample period is July 2, 1962 to December 31, 1980, and for our most comprehensive sample we have 4,471 ex-day portfolios $(T=4,471)$. Because the average $S E R$ has an asymptotic standard error of $T^{-1 / 2}$, a sample of this size implies a standard error of approximately 0.015 . If we adopt the convention of rejecting the null hypothesis when the sample average deviates from zero by more than two standard errors, an average $S E R$ with an absolute value as small as 0.03 would cause us to reject the null hypothesis in favor of the ex-day tax premium. On average our ex-day portfolios have an estimated standard deviation of about $0.8 \%$. Thus, an average excess ex-day return of $0.024 \%$ would imply an $S E R$ of 0.03 and cause us to reject the null hypothesis of no ex-day tax premiums. With four ex-days in a year, a $0.024 \%$ ex-day

\footnotetext{
${ }^{8}$ This procedure assumes that the parameters are stationary over the 60 day period. As a check for the sensitivity of our results to this assumption, we also estimated $\overline{R P}_{t}$ 's and $\hat{\sigma}_{t}$ 's over the 40 day period beginning 50 days before and ending 11 days before the ex-day. This different estimation period did not alter any of our conclusions.
} 
premium implies an annual excess return of less than one-tenth of one percent! It seems unreasonable to alter our beliefs on the basis of evidence with such trifling economic consequences. ${ }^{9}$

The problems of interpreting large samples may be avoided by casting our inferences in terms of a real-world decision maker. In particular, we provide a Bayesian interpretation of our results via posterior odds ratios. The posterior odds ratio simply represents the ratio of the probabilities of the null to the alternative hypothesis given the decision maker's prior beliefs and the sample information. With diffuse prior beliefs, the posterior odds ratios correspond to standard significance levels and would equal about 0.053 at the 0.05 level and 0.0101 at the 0.01 level. In presenting our results we use two weakly informative priors. Both cases assume that the null hypothesis of no tax premium is true with probability 0.5 . Our prior beliefs about the alternative hypotheses are represented as a 0.5 probability that (1) the mean ex-day $S E R$ is between -1 and +1 with uniform probability, and (2) the mean $S E R$ is distributed as normal with a mean of zero and standard deviation of $0.316{ }^{10.11}$ Besides reporting these posterior odds ratios, we also report standard significance levels.

\subsection{Empirical results}

\subsubsection{A sample of taxable distributions by common stocks}

Our most comprehensive sample consists of all taxable distributions by New York Stock Exchange (N.Y.S.E.) common stocks during the period July 2,

\footnotetext{
${ }^{4}$ If we use a one-tailed test, which seems appropriate given our alternative hypothesis, the problem is further exacerbated

${ }^{10}$ For the uniform prior the posterior odds ratio equals

$$
K_{\mathrm{U}}=\mathrm{e}^{-(T / 2) \overline{S E R} \bar{R}^{2}} / \frac{1}{2} \int_{-1}^{1} \mathrm{e}^{-(T / 2)(u-S E R)^{2}} d u,
$$

where $\overline{S E R}$ is the sample mean. Assuming that $\overline{S E R}$ is well within the -1 to +1 limits, $K_{\mathrm{U}}$ may be approximated as

$$
K_{\mathrm{U}} \approx 2(T / 2 \pi)^{1 / 2} \mathrm{e}^{-(T / 2) \overline{S E R}^{2}} .
$$

With the normal prior the posterior odds ratio equals

$$
K_{\mathrm{N}}=\mathrm{e}^{-(T / 2) \overline{S E R}^{2}} /(2 \pi \times 0.316)^{-1 / 2} \int_{-\infty}^{\infty} \mathrm{e}^{-\left(u^{2} / 0.2\right)-(T / 2)(u-\overline{S E R})^{2}} d u .
$$

See Zellner (1971, pp. 303-304).

${ }^{11} \mathrm{We}$ chose the standard deviation of 0.316 for the normal to make the bounds of our prior distributions consistent with each other. To get an economic feel for these priors, note that using the average standard deviation of our ex-day portfolio returns $(0.8 \%)$ and assuming the average quarterly dividend yield is 1 percent, an $S E R$ of 1.0 implies an average tax premium coefficient, $\left(\tau_{\mathrm{d}}-\tau_{\mathrm{g}}\right) /\left(1-\tau_{\mathrm{g}}\right)$, equal to 0.8 .
} 


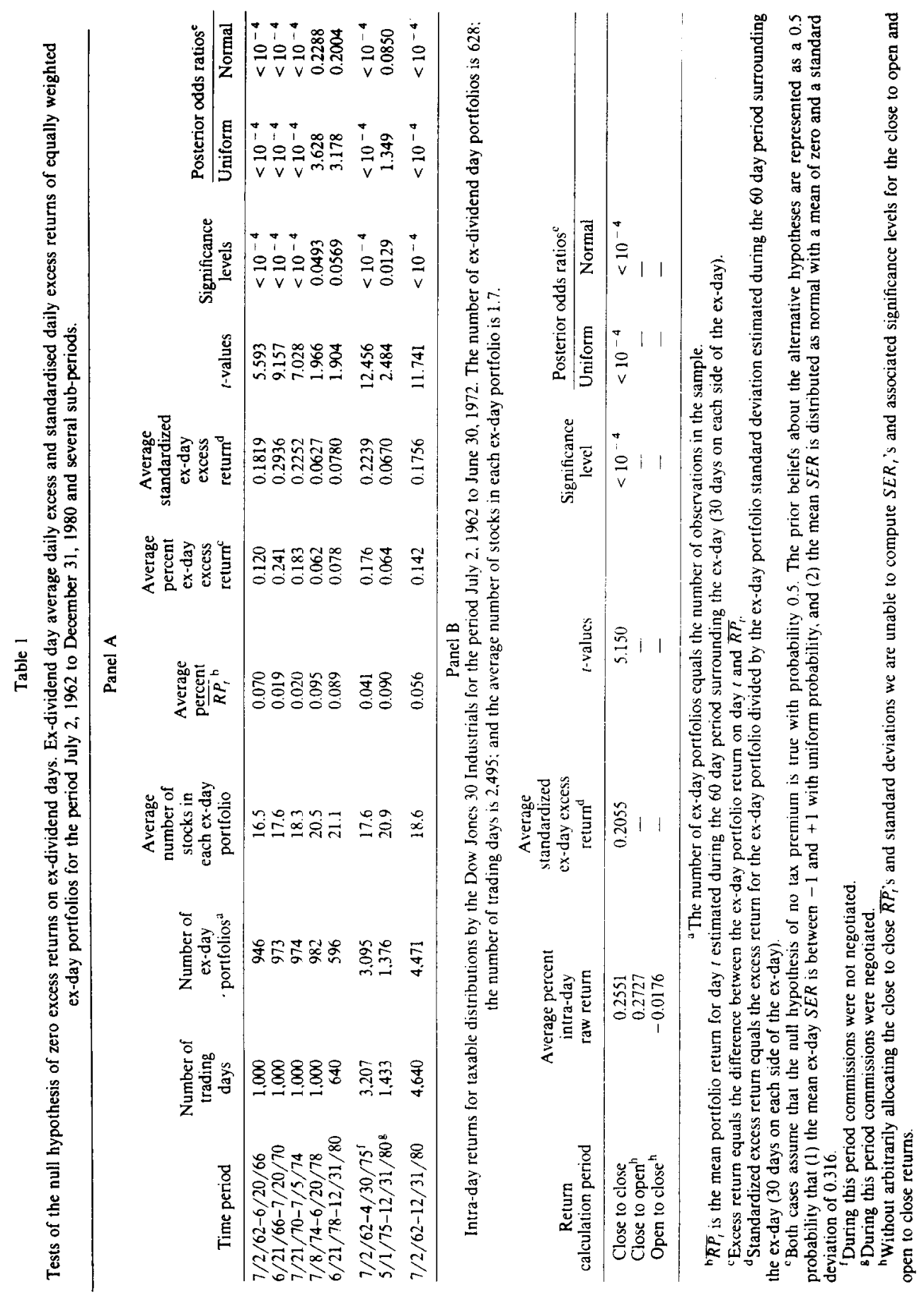


1962 to December 31,1980 . The sample includes more than 83,000 taxable distributions on 4,471 unique ex-dividend days. ${ }^{12}$ Panel $A$ of table 1 reports the results for this sample of taxable distributions. For the entire sample period of July 2, 1962 to December 31, 1980, the data strongly favor the hypothesis of an ex-day tax premium: for both priors the posterior odds exceed 10,000 to 1 against the null hypothesis of no ex-day premium.

The results for the shorter periods tell an equally interesting story. The first three subperiods predate negotiated commissions and have posterior odds exceeding 10,000 to 1 against the null hypothesis. In contrast, the last two subperiods are coincident with negotiated commissions and generally favor the null hypothesis of no ex-day tax premium. This pattern is repeated when the entire sample period is broken into the pre-negotiated commission period $(7 / 2 / 62-4 / 30 / 75)$ and the post-negotiated commission period $(5 / 1 / 75-12 / 31 / 80)$. These results are consistent with the notion that a significant drop in effective transactions costs coincided with the introduction of negotiated commissions.

The results of panel $\mathrm{A}$ in table 1 are based on returns which are calculated with closing prices; however, on ex-dividend days securities open without the dividend. Thus, ex-dividend day tax premiums should occur from the close on the day before the ex-day to the open on the ex-day, not from the open to the close on the ex-day. We check the temporal nature of the ex-day returns by collecting opening prices for the securities included in the Dow Jones 30 . These securities are heavily traded, and hence we expect that their opening prices equal the market clearing prices. The New York Times is our source for the opening prices; but unfortunately, the New York Times stopped reporting opening prices on September 29, 1972. Thus, we chose to limit our close to open sample period to the ten-year period July 2, 1962 to June 30, 1972.

Panel $\mathrm{B}$ of table 1 reports our close to open and open to close returns along with the close to close returns for the Dow Jones 30 over the ten year sample period. ${ }^{13}$ In comparing panels $\mathrm{A}$ and $\mathrm{B}$ we see that the close to close returns for the Dow are similar to those of all taxable distributions. Furthermore, the close to open returns suggest that the ex-day effect occurs overnight and not during the ex-day. ${ }^{14}$ This timely response of prices is precisely what we would expect if dividends are taxed more heavily than capital gains.

\footnotetext{
${ }^{12}$ The common stock return data used in this study are taken from the CRSP Daily Return File, and the dividend announcement dates and ex-dividend dates are taken from the CRSP Monthly Master File.

${ }^{13}$ Without arbitrarily allocating the close to close $\overline{R P}$ 's and $\hat{\sigma}_{t}$ 's we are unable to compute $S E R$,'s and the associated significance levels for the close to open and open to close returns. Thus, only the raw return percentages are reported in pancl $B$.

${ }^{14}$ Cash dividends are actually received some time after the ex-day. For our sample, the average time between the ex-date and the payment date is 25.7 calendar days. Thus, when we account for the time value of the money, this delay in payment should cause an ex-day price adjustment that is
} 


\subsubsection{Preferred stock sample}

The results reported in table 1 generally support the hypothesis that ex-day returns include a tax premium. Ex-day returns are both large and timely, and they tend to change in accordance with changes in the nominal cost of transacting. Given our discussion of transaction costs, it is interesting to comparc the results of this sample to a high yiclding sample of sccurities. If the transaction costs/tax effect interpretation is correct, the ex-day premium for high yielding securities should exceed those of table 1 during the pre-negotiated commission period and be approximately equal during the negotiated commission period. A convenient sample of high yielding securities is a preferred stock sample.

Our preferred stock sample consists of all N.Y.S.E. non-convertible preferred stocks that had at least one round lot transaction on $95 \%$ or more of the days during the period from January 1, 1974 to December 31, 1981. ${ }^{15}$ During the sample period of 1974 through 1981 these securities had a total of 708 ex-days which occurred on 493 trading days. Table 2 reports the preferred stock results for the entire sample period, for two shorter sub-periods, and for the post-negotiated commission period. Unlike the common stock sample, the ex-day returns of our preferred stock sample reveal significantly negative excess returns on their ex-days.

Similar results have been documented for high yielding common stocks by Elton and Gruber (1970), Kalay (1982), and Miller and Scholes (1982). Elton and Gruber, and Kalay report that on ex-days high yielding common stock prices fall by an amount greater than the dividend (i.e., negative excess returns) and Miller and Scholes (1982) report a negative dividend coefficient for the highest dividend yield group (i.e., a negative dividend premium). These results are consistent with tax-induced dividend clienteles. For example, our preferred stock results may be explained if the marginal purchasers of preferred stocks are corporations. Corporations are able to exclude $85 \%$ of any dividends received from taxable income whereas capital gains are taxable at rates as high as $46 \%$ if they are short-term gains. Thus corporations face a lower tax rate on dividends than capital gains implying a negative value for $\gamma_{1, i}$ in (3).

Although the existence of tax-induced dividend clienteles may be used to explain negative ex-day excess returns for high yielding securities, without a complete specification of the respective dividend clienteles this modified version of the tax hypothesis is difficult to test. Furthermore, there is the danger that this modified tax hypothesis may be used to explain virtually any set of

\footnotetext{
less than one-for-one even in the absence of any tax effects. Assuming an average dividend yield of $1 \%$ and an annual risk free rate of $6 \%$, the average delay of 25.7 days implies that the returns in table 1 are overstated by $0.0042 \%$.

${ }^{15}$ The sample includes 44 preferred stocks, and the returns on these securities were obtained from Compuserve in machine readable form.
} 


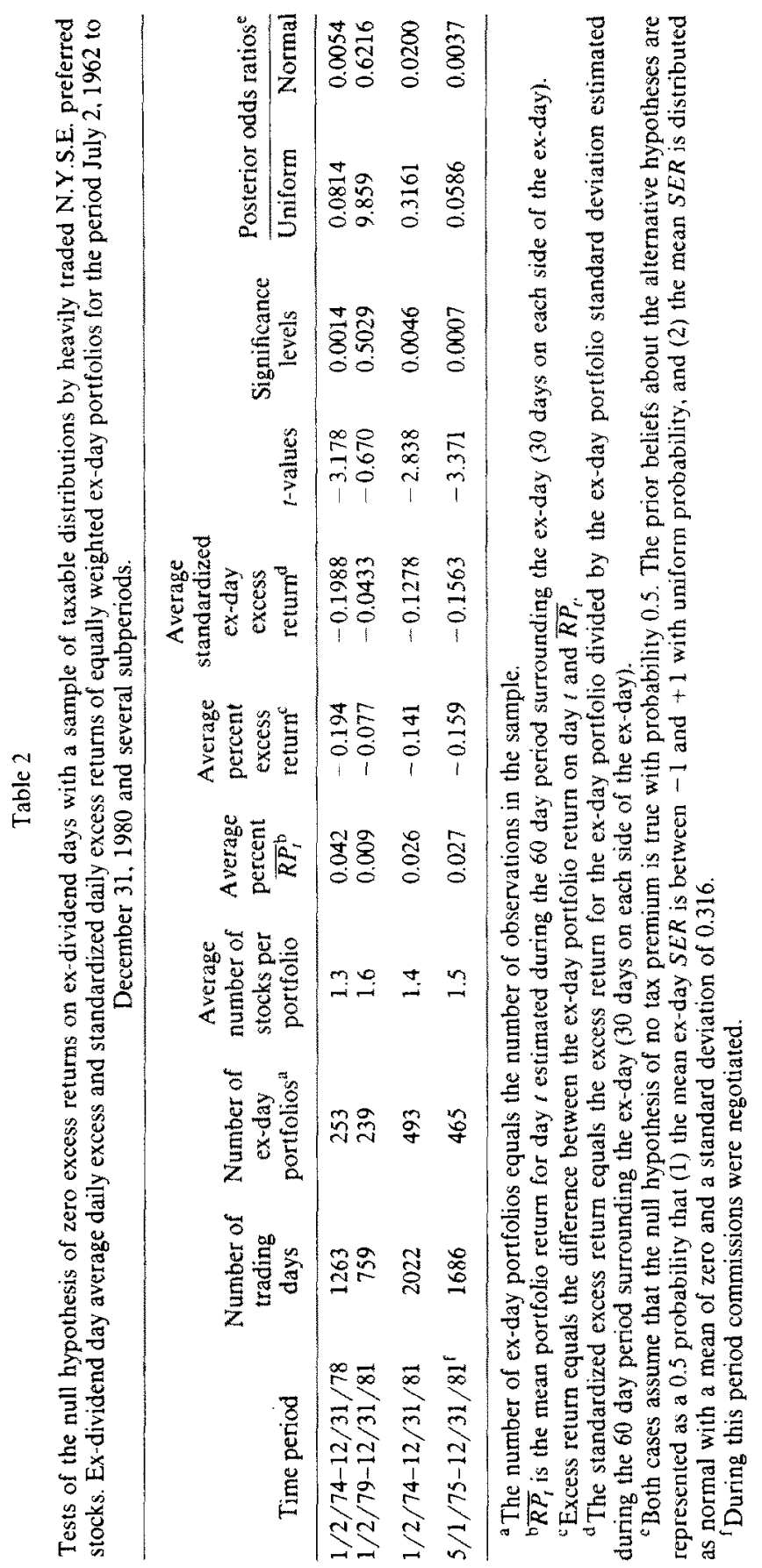


ex-day results. As a further investigation of this version of the tax hypothesis we examine the ex-day behavior of distributions which should have no tax implications. If these distributions exhibit unusual ex-day returns it is unclear what, if any, conclusions may be safely drawn from the observed ex-day returns of taxable distributions.

\subsubsection{Non-taxable distributions of common stocks}

These distributions provide an attractive control sample for investigating the ex-day tax interpretation. If tax effects are the only cause for the positive and the negative excess returns on the ex-days, the ex-day returns for non-taxable distributions should exhibit no ex-day premium. Positive or negative ex-day premiums for non-taxable distributions suggests the possibility of a non-tax based explanation of ex-day returns.

There are basically two types of non-taxable distributions: (1) stock dividends and splits and (2) non-taxable cash distributions. Stock dividends and splits are, with a few exceptions, ${ }^{16}$ tax neutral. Non-taxable cash distributions are typically payments of accumulated surpluses that have not been subject to corporate income taxes and qualify as return of capital. These non-taxable cash dividends reduce the investor's tax basis dollar for dollar. We construct a stock dividend and split sample by considering all N.Y.S.E. common stocks having a stock dividend or split during the period July 2, 1962 to December 31, 1980. From this group we exclude all distributions having any dividend announcements or other ex-dividend days occurring within a period of five days on either side of its own ex-day. The non-taxable cash distribution sample includes all such distributions by N.Y.S.E. common stocks during the period July 2, 1962 to December 31, 1980 except when those distributions occurred simultaneously with another type of distribution.

The results of the stock dividend and split sample are reported in panel A of table 3. For the entire period July 2, 1962 to December 31, 1980 there were 2.110 'clean' stock dividends and splits by N.Y.S.E. common stocks. These distributions occurred on 1,550 different ex-days. The results of panel $A$ of table 3 bear a striking resemblance to panel $\mathrm{A}$ of table 1 . For the entire sample period $(7 / 2 / 62-12 / 31 / 80)$, the average raw return on the ex-day is $0.477 \%$ of which $0.387 \%$ is the excess return. The average $S E R$ of 0.1998 is large and statistically significant: for both priors, the posterior odds are 10.000 to 1 against the null hypothesis of no ex-day premium. When the total sample period is broken into five subperiods, every subperiod, with the exception of the first subperiod $(7 / 2 / 62-6 / 20 / 66)$, shows a statistically significant positive ex-day premium. Had we inadvertently included these securities in our taxable

\footnotetext{
1t The exception occurs when shareholders have the option of receiving ash. We exclude these distributions from our sample.
} 


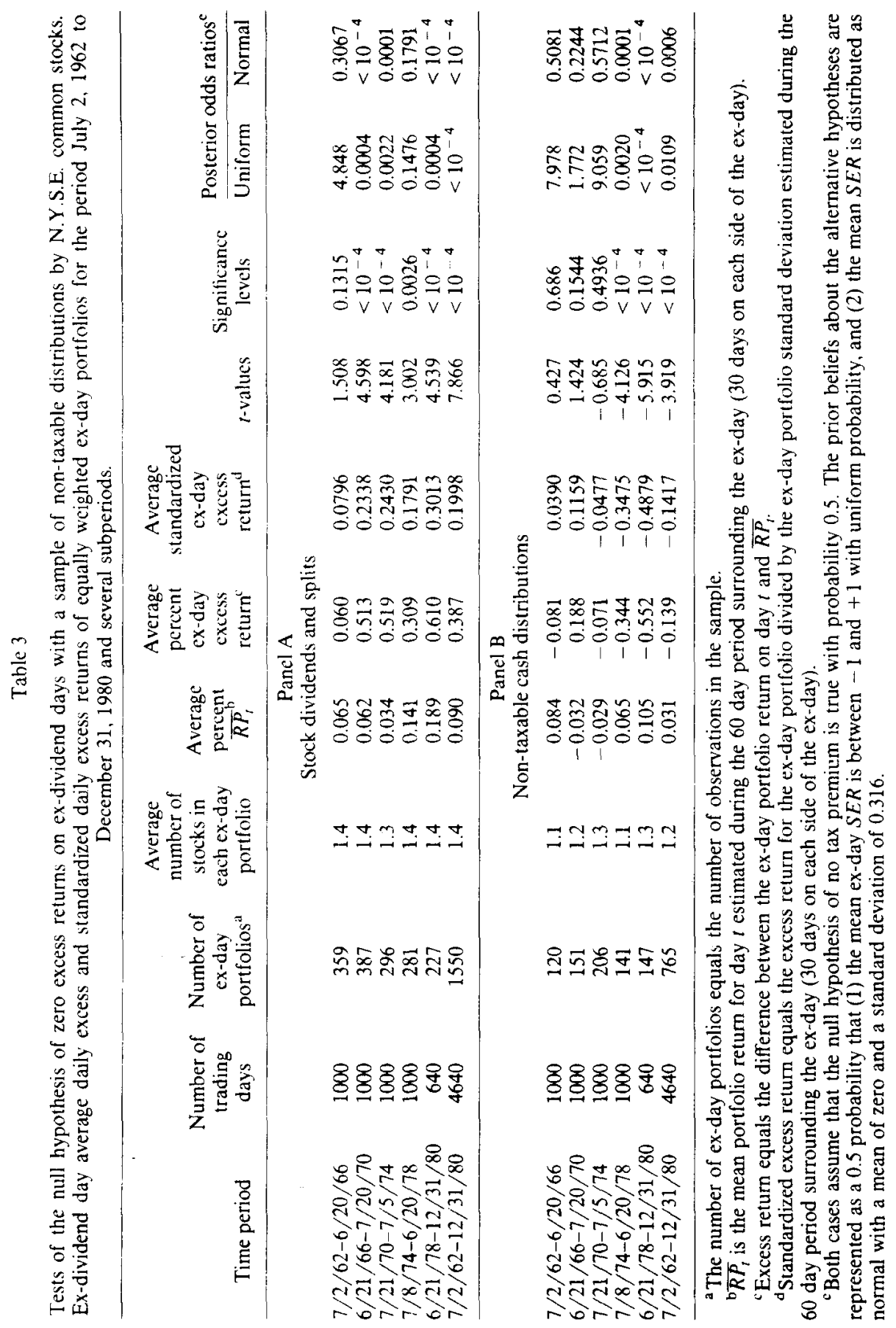


distribution sample, the results of table 1 would have been more supportive of the ex-day tax premium hypothesis. However, when isolated as a tax neutral sample, these results cast doubt on our ability to infer the differential tax rates between dividends and capital gains from the ex-dividend day pricing behavior.

Note that in the stock dividends and splits sample, we are dealing with the ex-days, not the announcement days; furthermore, we excluded all distributions having any announcements of either cash distributions or stock dividends and splits or any ex-dividend days occurring within a period of five days on either side of its own ex-day. Thus, the positive excess returns cannot be attributed to the announcements (or the expectations of the announcements) of higher cash dividends that tend to follow stock splits and dividend [e.g., Fama, Fisher, Jensen, and Roll (1969)].

Our sample of non-taxable cash distributions includes 935 distributions which resulted in 765 unique ex-days. The results for this sample are shown in panel $\mathrm{B}$ of table $3 .^{17}$ For the entire sample period $(7 / 2 / 62-12 / 31 / 80)$, the average excess return is $-0.139 \%$, and the average $S E R$ of -0.1417 is large and statistically significant. Breaking the total sample into five subperiods reveals that the negative ex-day excess returns are confined to the two most recent subperiods of 1974-1978 and 1978-1980. Whatever is the cause for the negative excess returns, it seems to have become an important factor since the mid 70's.

The negative ex-day excess returns for the non-taxable dividend sample would be consistent with the tax effect hypothesis if these distributions did not reduce the basis used in calculating taxable capital gains thereby enabling the recipients to lower future capital gains taxes. However, these distributions do reduce the tax basis, and hence are tax neutral. Once again we have found ex-day returns which are inconsistent with the widely cited tax interpretation of ex-day pricing behavior.

It should be noted, however, that the inconsistency between the nontaxable cash distribution sample and the tax hypothesis is not as clear cut as are the results of the stock dividends and splits sample. Our sample of non-taxable cash distributions consists mainly of dividends paid by high yielding utility stocks. The average quarterly dividend yield of this sample is $2.12 \%$ which is approximately equal to the average yield of $2.09 \%$ for Kalay's highest yielding group. Combining the high yielding nature of these securities with the fact that the exact tax status of the distributions are uncertain until year end, it might be argued that the results of the non-taxable cash distribution are a manifestation

\footnotetext{
${ }^{17}$ Of the 935 non-taxable cash distributions, 917 are return of capital, 17 are liquidating dividends, and 1 is non-taxable cash distribution resulting from exchange and reorganization. The tests reported in panel $\mathrm{B}$ of table 3 were also conducted while excluding the liquidating dividends and the distribution resulting from exchange and reorganization. The results were virtually identical.
} 
Table 4

Summary and comparison of ex-dividend day pricing behavior. ${ }^{a}$

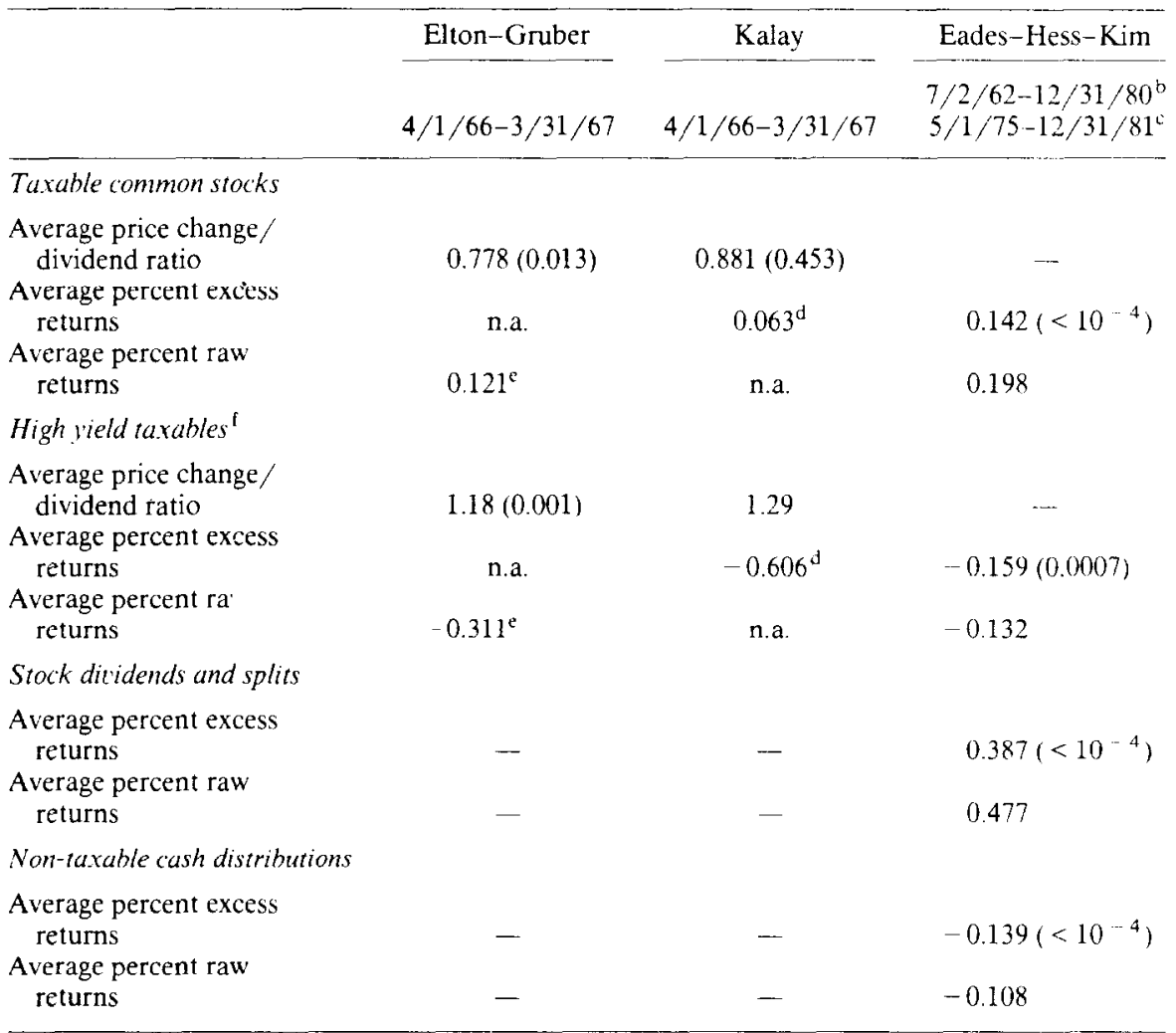

"When computable or reported, significance levels are shown within parentheses.

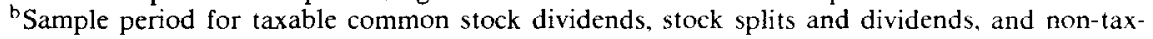
able cash distribution.

'Sample period for preferred stock dividends.

'Estimated from Kalay's table 2 by computing (1) for each dividend yield group, (the mean dividend yield) minus (the mean 'excess' price change to dividend ratio times the mean dividend yield) and (2) the average for the twenty groups.

'Estimated from Elton-Gruber's tables 1 and 3 by following a similar procedure to the one described in footnote $\mathrm{d}$.

'The high yield taxables represent the common stock dividends in the top decile in terms of dividend yields for Elton-Gruber; the top 5\% common stock dividends for Kalay; and heavily traded preferred stock dividends for Eades-Hess-Kim. 
of tax-induced dividend clienteles. For example, had the capital market believed these non-taxable distributions to be fully taxable, the negative ex-day excess returns would be consistent with the ex-day results of high yielding common stocks and preferred stocks. Such an interpretation implies that the marginal investors in our sample of securities that made non-taxable cash distributions faced higher tax rates on capital gains than on dividends.

However, this clientele interpretation overlooks the market's ability to form rational expectations. Recall that our sample includes only those distributions that are 100\% non-taxable and excludes those securities that had more than one type of distribution on the same ex-day. Thus, if the market forms rational expectations, it would judge the certainty equivalent taxable yield of these distributions to be low, not high. Ignoring transaction costs, the dividend clientele hypothesis predicts that these dividends will attract investors with relatively high tax rates on dividend income. These clienteles will demand a positive ex-day premium, not the negative premium reported in panel $B$ of table 3. If we allow for positive transaction costs, clienteles may not change; nevertheless, we would still expect a small ex-day effect associated with the low certainty equivalent taxable yields of these dividends. However, during the period of 1974 to 1980 the ex-day excéss returns for the non-taxable cash distributions are more negative than those reported for the preferred stock dividends in table 2. In sum, even if we allow the tax status of the non-taxable cash dividends to be uncertain on the ex-days, the results are not consistent with the joint hypotheses of rational expectations and tax-induced dividend clienteles.

\subsubsection{Summary of ex-dividend day evidence}

Table 4 summarizes our ex-day results for all four types of distributions. The results for the preferred stock sample are reported under the heading ' $\mathrm{High}$ Yield Taxables'. The table also shows the average raw returns and excess returns that are imputed from the average price change to dividend ratios reported by Elton-Gruber and Kalay. When appropriate, significance levels are reported within parentheses.

Our ex-day results for taxable common stock dividends and preferred stock dividends have signs that are consistent with the average raw returns and excess returns imputed from the statistics reported by Elton-Gruber and Kalay. The difference between our point estimates and those of Elton-Gruber is due to different sample periods and types of securities; the difference with Kalay is further exacerbated by Kalay's methodology. ${ }^{18}$ On balance, our

\footnotetext{
${ }^{18}$ Kalay estimated expected returns for securities using the period July 1962 to December 1965 and calculated the dividend price change ratio using Elton and Gruber's sample period of April 1966 to March 1967. Thus, the average excess returns imputed from his 'excess' price change to dividend ratios represent the differences between the average ex-day returns during the sample
} 
results are consistent with those of Elton-Gruber and Kalay: The ex-day pricing behavior of taxable common stock dividends is consistent with the simple tax hypothesis that dividends are taxed at a higher rate than capital gains. The ex-day pricing behaviors of preferred stocks and the high yielding common stocks are consistent with the modified tax hypothesis of dividend clienteles.

When we examine the ex-day pricing behavior of non-taxable distributions that have not been examined by previous authors, we find surprising results. The securities that have stock dividends and splits provide significantly positive excess returns on their ex-days. Because these distributions have no tax implications, the positive excess returns cannot be tax premiums. In selecting the stock dividend and split sample, we excluded all distributions having any dividend announcement or other ex-dividend days occurring within a period of five days on either side of its own ex-day; thus, the positive excess returns cannot be attributed to the announcements (or the expectations of the announcements) of higher cash dividends following the announcements of stock dividends and splits.

The securities that paid non-taxable cash distributions show an equally puzzling ex-day pricing behavior. Even when we assume the tax status of these distributions are uncertain, the negative ex-day excess returns are not consistent with the joint hypotheses of rational expectations and tax-induced dividend clienteles. These results suggest that we may have an ex-day pricing anomaly, and it is to this issue that we now turn.

\section{The ex-dividend period anomaly}

The ex-dividend day pricing behavior of stock dividends and splits and non-taxable cash distributions is not consistent with the tax interpretation of ex-day returns. At this point these results are more appropriately described as an ex-day anomaly. This conclusion is similar to that reached by Black and Scholes (1973) who found unusual return behavior for several days surrounding the ex-day of taxable common stock dividends. In order to document the extent of the anomaly, the returns of the taxable distributions sample, the preferred stock sample, the stock dividends and splits sample, and the nontaxable cash distributions sample are examined for five days on each side of

period of April 1966 to March 1967 and the average returns during the estimation period of July 1962 to the end of 1965 . The sample period of April 1966 to March 1967 was originally selected by Elton and Gruber because the market was relatively flat during the period. Specifically, the average daily market return during July 1962 to the end of 1965 was $0.07 \%$ whereas the average daily market return during April 1966 to March 1967 was only $0.03 \%$. As a result. the excess returns imputed from Kalay's measure considerably underestimate the true excess returns. This downward bias does not exist in Kalay's measure that is based on the market model returns; unfortunately, the information reported by Kalay is insufficient to impute the average excess return based on the market model. 
Table 5

Tests of the null hypothesis of zero excess returns for the ex-dividend period with a sample of all taxable distributions by N.Y.S.E. common stocks. Average daily excess and standardized daily excess returns of equally weighted ex-day portfolios for each day in the ex-dividend period for the period July 2, 1962 to December 31,1980 . The number of ex-dividend day portfolios is 4,471 ; the number of trading days is 4,640 ; and the average number of stocks in each ex-day portfolio is 18.6.

\begin{tabular}{cccccccc}
\hline $\begin{array}{c}\text { Trading day } \\
\text { relative } \\
\text { to ex-day }\end{array}$ & $\begin{array}{c}\text { Average } \\
\text { percent } \\
\text { excess } \\
\text { return }^{\mathrm{a}}\end{array}$ & $\begin{array}{c}\text { Average } \\
\text { standardized } \\
\text { excess } \\
\text { return }^{\mathrm{b}}\end{array}$ & $\boldsymbol{t}$-statistic & $\begin{array}{c}\text { Significance } \\
\text { level }\end{array}$ & \multicolumn{2}{l}{\begin{tabular}{l} 
Posterior odds ratios \\
\cline { 5 - 6 }
\end{tabular}} \\
\hline-5 & 0.067 & 0.0631 & 4.218 & $<10^{-4}$ & 0.0073 & 0.0005 \\
-4 & 0.046 & 0.0621 & 4.155 & $<10^{-4}$ & 0.0095 & 0.0006 \\
-3 & 0.061 & 0.0832 & 5.561 & $<10^{-4}$ & $<10^{-4}$ & $<10^{-4}$ \\
-2 & 0.066 & 0.0892 & 5.968 & $<10^{-4}$ & $<10^{-4}$ & $<10^{-4}$ \\
-1 & 0.188 & 0.2340 & 15.647 & $<10^{-4}$ & $<10^{-4}$ & $<10^{-4}$ \\
Ex-day & 0.142 & 0.1756 & 11.741 & $<10^{-4}$ & $<10^{-4}$ & $<10^{-4}$ \\
+1 & -0.053 & -0.0651 & -4.355 & $<10^{-4}$ & 0.0041 & 0.0003 \\
+2 & -0.058 & -0.0734 & -4.911 & $<10^{-4}$ & 0.0003 & $<10^{-4}$ \\
+3 & -0.036 & -0.0405 & -2.707 & 0.0068 & 1.366 & 0.0824 \\
+4 & -0.046 & -0.0627 & -4.195 & $<10^{-4}$ & 0.0080 & 0.0005 \\
+5 & -0.043 & -0.0553 & -3.700 & 0.0002 & 0.0569 & 0.0037 \\
\hline
\end{tabular}

${ }^{a}$ Excess return equals the difference between the ex-day portfolio return on day $t$ and $\overline{R P}$ (the mean portfolio return for day $t$ estimated during the 60 day period surrounding the ex-day).

${ }^{\mathrm{b}}$ Standardized excess return equals the excess return for the ex-day portfolio divided by the ex-day portfolio standard deviation estimated during the 60 day period surrounding the ex-day ( 30 days on each side of the ex-day).

'Both cases assume that the null hypothesis of no tax premium is true with probability 0.5 . The prior beliefs about the alternative hypotheses are represented as a 0.5 probability that (1) the mean ex-day $S E R$ is between -1 and +1 with uniform probability, and (2) the mean $S E R$ is distributed as normal with a mean of zero and a standard deviation of 0.316 .

the ex-day. Unusual security returns during this 'ex-dividend period' would be further evidence of a general anomaly and cast further doubt on the ability to infer differential tax rates between dividends and capital gains from the ex-dividend day pricing behavior.

The ex-dividend period returns are reported in tables 5,6 and $7 .^{19}$ These results indicate that each sample exhibits anomalous behavior during the ex-dividend period. The common stock taxable distribution sample shows the

${ }^{19}$ The tests reported in tables 5,6 and 7 were also conducted by excluding the ex-dividend period returns in calculating $\overline{R P}_{t}$ and $\hat{\sigma}_{t}$. This procedure was used to eliminate any influence of the surrounding day behavior upon the calculation of $S E R$ 's. However, the results were not qualitatively distinguishable from those reported in this paper. Although we report the results only for the entire sample periods, the tests were also conducted for each of the shorter periods reported in table 1 including the post-negotiated commission period. Unlike the ex-day returns, the exdividend period returns are qualitatively the same for the pre- and post-negotiated commissions periods. 


\section{Table 6}

Tests of the null hypothesis of zero excess returns for the ex-dividend period with a sample of heavily traded N.Y.S.E. preferred stocks. Average daily excess and standardized daily excess returns of equally weighted ex-day portfolios for each day in the ex-dividend period for the period July 2, 1974 to December 31, 1981. The number of ex-dividend day portfolios is 465 ; the number of trading days is 4,640; and the average number of stocks in each ex-day portfolio is 1.5 .

\begin{tabular}{ccccccc}
\hline $\begin{array}{c}\text { Trading day } \\
\text { relative } \\
\text { to ex-day }\end{array}$ & $\begin{array}{c}\text { Average } \\
\text { percent } \\
\text { excess } \\
\text { return }^{\mathbf{a}}\end{array}$ & $\begin{array}{c}\text { Average } \\
\text { standardized } \\
\text { excess return }^{b}\end{array}$ & $\begin{array}{c}\text { t-statistic } \\
\text { Significance } \\
\text { level }\end{array}$ & \multicolumn{2}{c}{$\begin{array}{c}\text { Posterior odds ratios } \\
\text { Uniform }\end{array}$} & Normal \\
\hline-5 & 0.012 & 0.0440 & 0.977 & 0.3286 & 10.993 & 7.793 \\
-4 & 0.055 & 0.0896 & 1.989 & 0.0467 & 2.449 & 1.753 \\
-3 & 0.010 & 0.0761 & 1.690 & 0.0911 & 4.250 & 3.031 \\
-2 & 0.151 & 0.1367 & 3.035 & 0.0024 & 0.1770 & 0.1288 \\
-1 & 0.242 & 0.2784 & 6.181 & $<10^{-4}$ & $<10-4$ & $<10-4$ \\
Ex-day & -0.141 & -0.1278 & -2.838 & 0.0045 & 0.3161 & 0.2293 \\
+1 & -0.199 & -0.1696 & -3.766 & 0.0002 & 0.0148 & 0.0109 \\
+2 & -0.075 & -0.0840 & -1.865 & 0.0622 & 3.112 & 2.224 \\
+3 & 0.075 & 0.0395 & 0.877 & 0.3805 & 12.060 & 8.545 \\
+4 & 0.014 & -0.0028 & -0.0622 & 0.9504 & 17.682 & 12.497 \\
+5 & -0.031 & -0.0374 & 0.8304 & 0.4063 & 12.549 & 8.889 \\
\hline
\end{tabular}

${ }^{a}$ Excess return equals the difference between the ex-day portfolio return on day $t$ and $\bar{R} \bar{P}_{t}$ (the mean portfolio return for day $t$ estimated during the 60 day period surrounding the ex-day).

${ }^{b}$ Standardized excess return equals the excess return for the ex-day portfolio divided by the ex-day portfolio standard deviation estimated during the 60 day period surrounding the ex-day ( 30 days on each side of the ex-day).

"Both cases assume that the null hypothesis of no tax premium is true with probability 0.5 . The prior beliefs about the alternative hypotheses are represented as a 0.5 probability that (1) the mean ex-day $S E R$ is beiween -1 and +1 with uniform probability, and (2) the mean $S E R$ is distributed as normal with a mean of zero and a standard deviation of 0.316 .

most prominent aberration in returns during the period, but all four samples have large returns over the period day -2 to day +2 (where day 0 is the ex-day). The overall impression here is that abnormal returns are not uniquely associated with the ex-day; indeed, for all but the stock dividends and splits sample, the absolute value of the ex-day excess returns are smaller than the day +1 or the day -1 returns or both. This evidence not only weakens the ability to test the tax hypothesis with the ex-dividend day pricing bchavior but also suggests that the relative price drops on ex-days cannot be used to measure differential tax rates between dividends and capital gains.

\section{Alternative explanations for the pricing behavior during the ex-dividend period}

We have documented anomalous patterns in security pricing behavior during the ex-dividend period. For each of the four types of distributions examined, the tax effect hypothesis, as stated in section 2 , is unable to explain 
Table 7

Tests of the null hypothesis of zero excess returns for the ex-dividend period with a sample of non-taxable distributions by N.Y.S.E. common stocks. Average daily excess and standardized daily excess returns of equally weighted ex-day portfolios for each day in the ex-dividend period for the period July 2, 1962 to December 31, 1980.

\begin{tabular}{|c|c|c|c|c|c|c|}
\hline \multirow{2}{*}{$\begin{array}{l}\text { Trading day } \\
\text { relative } \\
\text { to ex-day }\end{array}$} & \multirow{2}{*}{$\begin{array}{l}\text { Average } \\
\text { percent } \\
\text { excess } \\
\text { return }\end{array}$} & \multirow{2}{*}{$\begin{array}{c}\text { Average } \\
\text { standardized } \\
\text { excess return }\end{array}$} & \multirow[b]{2}{*}{ t-statistic } & \multirow{2}{*}{$\begin{array}{c}\text { Significance } \\
\text { level }\end{array}$} & \multicolumn{2}{|c|}{ Posterior odds ratios } \\
\hline & & & & & Uniform & Normal \\
\hline \multicolumn{7}{|c|}{$\begin{array}{l}\text { Panel A } \\
\text { Stock dividends and stock splits. The number of ex-dividend day portfolios is } 1,550 \text {; the number of } \\
\text { trading days is 4,640; and the average number of stocks in cach cx-day portfolio is } 1.4 \text {. }\end{array}$} \\
\hline-5 & -0.016 & -0.0258 & -1.017 & 0.3092 & 18.753 & 1.1822 \\
\hline-4 & 0.070 & 0.0159 & 0.626 & 0.5312 & 25.824 & 1.6281 \\
\hline-3 & 0.001 & 0.0037 & 0.147 & 0.8829 & 31.081 & 1.9588 \\
\hline-2 & 0.059 & 0.0314 & 1.238 & 0.2157 & 14.630 & 0.9222 \\
\hline-1 & 0.194 & 0.0969 & 3.815 & $<10^{-4}$ & 0.0217 & 0.0014 \\
\hline Ex-day & 0.387 & 0.1998 & 7.866 & $<10^{-4}$ & $<10^{-4}$ & $<10^{-4}$ \\
\hline+1 & 0.128 & 0.0666 & 2.624 & 0.0088 & 1.010 & 0.0637 \\
\hline+2 & 0.151 & 0.0748 & 2.947 & 0.0032 & 0.411 & 0.0259 \\
\hline$+\overline{3}$ & 0.112 & 0.0632 & 2.489 & 0.0128 & 1.421 & 0.0896 \\
\hline+4 & -0.025 & 0.0058 & 0.229 & 0.8328 & 30.604 & 1.9290 \\
\hline+5 & -0.004 & -0.0029 & -0.113 & 0.9100 & 31.209 & 1.9668 \\
\hline
\end{tabular}

Panel B

Non-taxable cash distributions. The number of ex-dividend day portfolios is 765 ; the number of trading days is 4,640: and the average number of stocks in each ex-day portfolio is 1.2 .

$\begin{array}{crrrlcl}-5 & 0.198 & 0.1296 & 3.585 & 0.0030 & 0.0358 & 0.0023 \\ -4 & 0.119 & 0.0374 & 1.033 & 0.3016 & 12.924 & 0.8148 \\ -3 & 0.122 & 0.1122 & 3.104 & 0.0019 & 0.1789 & 0.0113 \\ -2 & 0.042 & 0.0799 & 2.209 & 0.0271 & 1.920 & 0.1211 \\ -1 & 0.232 & 0.1633 & 4.517 & <10^{-4} & 0.0008 & <10^{-4} \\ \text { Ex-day } & -0.139 & -0.1417 & -3.918 & <10^{-4} & 0.0102 & 0.0006 \\ +1 & -0.275 & -0.1496 & -4.137 & <10^{-4} & 0.0042 & 0.0003 \\ +2 & -0.047 & -0.0653 & -1.807 & 0.0708 & 4.319 & 0.2723 \\ +3 & -0.022 & -0.0254 & -0.703 & 0.4821 & 17.242 & 1.087 \\ +4 & -0.031 & -0.0260 & -0.720 & 0.4716 & 17.040 & 1.074 \\ +5 & -0.221 & -0.1113 & -3.078 & 0.0021 & 0.1932 & 0.0122\end{array}$

${ }^{a}$ Excess return equals the difference between the ex-day portfolio return on day $t$ and $\overline{R P}$, (the mean portfolio return for day $t$ estimated during the 60 day period surrounding the ex-day).

${ }^{\mathrm{b}}$ Standardized excess return equals the excess return for the ex-day portfolio divided by the ex-day portfolio standard deviation estimated during the 60 day period surrounding the ex-day ( 30 days on each side of the ex-day).

"Both cases assume that the null hypothesis of no tax premium is true with probability 0.5 . The prior beliefs about the alternative hypotheses are represented as a 0.5 probability that (1) the mean ex-day $S E R$ is between -1 and +1 with uniform probability, and (2) the mean $S E R$ is distributed as normal with a mean of zero and a standard deviation of 0.316 . 
the anomalous pricing behavior. In this section we explore several alternative explanations for the pattern of ex-dividend period returns.

\subsection{Errors in the ex-dividend dates}

Errors in the recording of ex-dividend dates could explain the pattern of returns observed during the ex-dividend period. For example, if reported ex-dividend dates are too early, the returns on the reported ex-dividend day will be positively biased while the returns on the true ex-day will be negatively biased. This is particularly troublesome for stock splits. For example, an error in recording the date of a 2 for 1 split will result in a $100 \%$ excess return for a security. [This error will overstate the average excess return for the entire sample of stock dividends and splits by $0.05 \%(100 \% / 2110)$.] Thus as the first pass check in the recording of ex-dividend dates, we examine the frequency distributions of the raw returns and the $S E R$ 's for each of our samples and for each day in the ex-dividend period. Our visual inspection of the frequency distributions does not reveal any blatant outliers or any apparent differences among the distributions. ${ }^{20}$ We also trimmed our samples by discarding $10 \%$ and then $25 \%$ of both tails. If errors in the recording of the ex-dividend dates are driving our results, we would expect this effect to be reduced with the removal of extreme values. As might be expected from our inspection of the frequency distributions, sample trimming had no impact upon our results.

As a more direct check on the quality of data, we randomly selected 50 trading days during which 903 taxable common stock dividends and 53 non-taxable cash distributions went ex-dividend. For these 956 CRSP ex-dates we were able to verify manually all but one of the ex-dates with the Wall Street Journal or Standard and Poor's Daily Stock Price Record. Assuming an average dividend yield of $2 \%$, an error rate of about one-tenth of one percent would result in a bias of about $0.002 \%$ in terms of excess returns. Even for our sample sizes, such a bias is hardly material. Since recording errors in the stock dividends and splits sample have more dramatic effects, we doubled the number of trading days to be checked to 100 days. This resulted in 85 distributions and no errors were discovered. Collectively, this suggests that errors in recording ex-dividend dates are not responsible for our results.

\subsection{The day of the week effect}

Another attribute of the data that may systematically affect our results is the day of the week phenomenon. French (1980) and Gibbons and Hess (1981)

\footnotetext{
${ }^{20}$ It does reveal, however, that the ex-day returns are slightly skewed to the right, which motivated us to perform a non-parametric test for each of our samples during the ex-dividend period. These results are reported in section 4.5 .
} 
have documented that common stock returns are systematically low on Mondays. If taxable common stock dividends and stock dividends and splits tend to go ex on days other than Mondays, positive ex-day excess returns for these distributions may reflect the paucity of Monday returns. Quite to the contrary, tabulation of ex-days for common stocks by the day of the week shows the highest percentage of ex-days occurring on Mondays: $31.9 \%$ for taxable common stock dividends, $31.8 \%$ for stock dividends and splits, and $32.7 \%$ for nontaxable cash distribution. Thus, our results seem to be unrelated to the day of the week effect.

\subsection{The dividend announcement effect}

While it is highly unlikely that the use of wrong ex-days, outliers, or the Monday effect is even partially responsible for our results, it is possible that dividend announcements that precede ex-dividend days could contaminate our experimental design. It is well documented [e.g., Pettit (1972), Charest (1978), and Aharoney and Swary (1980)] that unexpected changes in dividends have significant impacts upon the common stock returns. In an extensive study on dividend announcement effects, Charest (1978) documents that the effects persist for a few days after the announcement. This persistence has a tendency to produce positive excess returns for several days after a dividend announcement with a positive initial market reaction and negative excess returns for several days following a dividend announcement with a negative initial market reaction.

If our sample of common stock ex-days is unbiased with respect to dividend announcements, we would expect to observe no systematic announcement effects during the ex-dividend period. Unfortunately, our sample excludes those cases when firms announced either an elimination or no resumption of a dividend. Since these cases are typically associated with a negative market reaction, their exclusion from our sample produces a positive selection bias. This suggests the possibility that the observed positive excess returns on the days preceding and including the ex-day may be due to the persistence of the dividend announcement effect. ${ }^{21}$

To investigate the effect of the positive announcement selection bias, we isolate two separate attributes of dividend announcements that might influence the ensuing ex-dividend period returns. First, we examine whether the exdividend period behavior is altered by the proximity of the announcement and the ex-day. Second, we investigate how the strength of the announcement influences security pricing behavior during the ex-dividend period.

\footnotetext{
${ }^{21}$ Although the persistence of the dividend announcement effect might be interpreted as evidence of market inefficiency, our concern here is to isolate the announcement and ex-day effects.
} 


\subsubsection{The proximity effect}

If the positive selection bias is responsible for the aberration in returns during the ex-dividend period, we should observe larger returns during the ex-dividend period the shorter the time lag between the announcement day and the ex-day. We isolate the proximity effect by dividing our sample of taxable common stock dividends into four groups. The first sample consists of those observations which have 5 days or less between the announcement day and the ex-day; second, 6 to 10; third, 11 to 15; and fourth, greater than 15 days. If the proximity of the announcement and the ex-day is responsible for the positive excess returns on days preceding and including the ex-day, then the positive excess returns should be most pronounced for the first group and least pronounced for the fourth group.

Table 8 reports the average excess returns, $S E R$ 's, and $t$-statistics for each of the four samples for days -5 through +5 . For the first sample, which includes the announcement days within the ex-dividend period, the average excess returns and $S E R$ 's on days -5 through 0 are always larger than the other samples. This result is consistent with the notion that the proximity of the announcement day and ex-day distorts the excess returns on days preceding and including the ex-day. Among the other samples (time lags of 6 to 10 days, 11 to 15 days, and greater than 15 days) there are no noticeable differences, suggesting that the distortions are mainly confined to the sample that includes announcement days in the ex-dividend period. In addition, for all three samples with time lags greater than 6 days the average returns on days -5 through 0 are positive and the $S E R$ 's during the period of days -3 through 0 are all significant; thus, the proximity of the announcement cannot explain the anomaly.

\subsubsection{The strength of the announcement}

While the results in the preceding section confirm our suspicion that the sample has a positive announcement selection bias, the proximity of the announcement and ex-day is unable to explain all of the anomalous return behavior during the ex-dividend period. As a further investigation of the effects of the announcement selection bias, we divide the sample of taxable common stock dividends into quartiles based upon the market's response to the announcement. The response is measured by calculating an announcement period $S E R$ for each dividend distribution over the period 7/2/62-12/30/80. An average return over a three day period including the dividend announcement day (as reported by CRSP) and one day on each side was used to capture both early and late market responses to the announcement. ${ }^{22}$ The announcement

\footnotetext{
${ }^{22}$ Early price reactions could be due to leaks to the market before the actual dividend announcement. On the other hand, if the announcement occurs after the close of trading, the following day's return reflects the information effect of the announcement.
} 
Table 8

The impact of dividend announcements upon returns during the ex-dividend period returns. The sample is all taxable distributions by common stocks on the N.Y.S.E. for the period July 2, 1962 to December 31,1980 (4,460 trading days), and is segmented by the time lag between the dividend announcement day and the ex-day.

\begin{tabular}{|c|c|c|c|c|c|c|}
\hline \multirow[b]{2}{*}{$\begin{array}{l}\text { Trading day } \\
\text { relative to } \\
\text { ex-day }\end{array}$} & \multicolumn{3}{|c|}{ Time lag of 1 to 5 trading days } & \multicolumn{3}{|c|}{ Time lag of 6 to 10 trading days } \\
\hline & $\begin{array}{l}\text { Average } \\
\text { percent } \\
\text { excess } \\
\text { return }\end{array}$ & $\begin{array}{l}\text { Average } \\
\text { standardized } \\
\text { excess } \\
\text { return }\end{array}$ & $t$-statistic & $\begin{array}{l}\text { Average } \\
\text { percent } \\
\text { excess } \\
\text { return }\end{array}$ & $\begin{array}{l}\text { Average } \\
\text { standardized } \\
\text { excess } \\
\text { return }\end{array}$ & $t$-statistic \\
\hline-5 & 0.0752 & 0.0640 & 3.98 & 0.0706 & 0.0393 & 2.47 \\
\hline-4 & 0.0637 & 0.0782 & 4.86 & 0.0508 & 0.0316 & 1.99 \\
\hline-3 & 0.0823 & 0.1090 & 6.78 & 0.0242 & 0.0341 & 2.15 \\
\hline-2 & 0.1091 & 0.1189 & 7.39 & 0.0406 & 0.0428 & 2.69 \\
\hline-1 & 0.2467 & 0.2127 & 13.22 & 0.1875 & 0.1845 & 11.61 \\
\hline Ex-day & 0.1533 & 0.1590 & 9.88 & 0.1300 & 0.1250 & 7.87 \\
\hline+1 & -0.0764 & -0.0643 & -4.00 & -0.0534 & -0.0553 & -3.48 \\
\hline+2 & -0.0461 & -0.0450 & -2.80 & -0.0944 & -0.0654 & -4.12 \\
\hline$+\overline{3}$ & -0.0570 & -0.0471 & -2.93 & -0.0371 & -0.0373 & -2.35 \\
\hline+4 & -0.0732 & -0.0658 & -4.09 & -0.0316 & -0.0393 & -2.47 \\
\hline \multirow[t]{2}{*}{+5} & 0.0404 & 0.0586 & 3.64 & -0.0591 & 0.0503 & -3.17 \\
\hline & \multicolumn{3}{|c|}{$\begin{array}{c}\text { The number of ex-dividend day } \\
\text { portfolios is } 3865 \text { and the } \\
\text { average number of stocks per } \\
\text { portfolio is } 6.4 \text {. }\end{array}$} & \multicolumn{3}{|c|}{$\begin{array}{c}\text { The number of ex-dividend day } \\
\text { portfolios is } 3961 \text { and the } \\
\text { average number of stocks per } \\
\text { portfolio is } 6.0 \text {. }\end{array}$} \\
\hline & \multicolumn{3}{|c|}{ Time lag of 11 to 15 trading days } & \multicolumn{3}{|c|}{ Time lag greater than 15 trading days } \\
\hline $\begin{array}{l}\text { Trading day } \\
\text { relative to } \\
\text { ex-day }\end{array}$ & $\begin{array}{l}\text { Average } \\
\text { percent } \\
\text { excess } \\
\text { return }\end{array}$ & $\begin{array}{l}\text { Average } \\
\text { standardized } \\
\text { excess } \\
\text { return }\end{array}$ & $t$-statistic & $\begin{array}{l}\text { Averagc } \\
\text { percent } \\
\text { excess } \\
\text { returna }\end{array}$ & $\begin{array}{l}\text { Average } \\
\text { standardized } \\
\text { excess } \\
\text { return }\end{array}$ & $t$-statistic \\
\hline-5 & 0.0378 & 0.0089 & 0.50 & 0.0244 & 0.0223 & 1.37 \\
\hline-4 & 0.0365 & 0.0314 & 1.78 & 0.0143 & 0.0234 & 1.43 \\
\hline-3 & 0.0665 & 0.0593 & 3.36 & 0.0463 & 0.0526 & 3.22 \\
\hline-2 & 0.0836 & 0.0716 & 4.05 & 0.0539 & 0.0565 & 3.46 \\
\hline-1 & 0.1585 & 0.1497 & 8.47 & 0.1558 & 0.1566 & 9.59 \\
\hline Ex-day & 0.1485 & 0.1110 & 6.28 & 0.0887 & 0.0882 & 5.40 \\
\hline+1 & -0.0529 & -0.0364 & -2.06 & -0.0429 & -0.0494 & -3.03 \\
\hline+2 & -0.0999 & -0.0687 & -3.89 & -0.0058 & -0.0148 & -0.91 \\
\hline+3 & -0.0074 & -0.0086 & -0.49 & -0.0023 & -0.0091 & -0.56 \\
\hline+4 & -0.0189 & -0.0380 & -2.15 & -0.0226 & -0.0235 & -1.44 \\
\hline \multirow[t]{2}{*}{+5} & -0.0422 & -0.0425 & -2.42 & -0.0066 & -0.0200 & -1.22 \\
\hline & \multicolumn{3}{|c|}{$\begin{array}{l}\text { The number of ex-dividend day } \\
\text { portfolios is } 3203 \text { and the } \\
\text { average number of stocks per } \\
\text { portfolio is } 3.8 \text {. }\end{array}$} & \multicolumn{3}{|c|}{$\begin{array}{l}\text { The number of ex-dividend day } \\
\text { portfolios is } 3752 \text { and the } \\
\text { average number of stocks per } \\
\text { portfolio is } 5.9 \text {. }\end{array}$} \\
\hline
\end{tabular}

${ }^{a}$ Excess return equals the difference between the ex-day portfolio return on day $t$ and $\overline{R P}_{f}$ (the mean portfolio return for day $t$ estimated during the 60 day period surrounding the ex-day).

${ }^{b}$ Standardized excess return equals the excess return for the ex-day portfolio divided by the ex-day portfolio standard deviation estimated during the 60 day period surrounding the ex-day ( 30 days on each side of the ex-day). 
period $S E R$ is then used to classify each individual observation into an announcement strength quartile such that the first quartile contains ex-days with the most negative announcement period $S E R$ 's and the fourth quartile contains ex-days with the most positive announcement period $S E R$ 's. For each day during the ex-dividend period, the ex-day portfolios are formed within each quartile and their $S E R$ 's are calculated.

To control for the announcement effect, we calculate the ex-dividend $S E R$ 's independently of the announcement period SER's by requiring that announcement period returns must not overlap with the ex-dividend period. Thus, our sample is restricted to those observations which have announcement periods at least 6 days before the ex-day, but no farther than 17 days before the ex-day. Only the 12 day period immediately preceding the ex-dividend period (days -17 through -6 ) can contain announcement period returns. This leaves days -30 through -18 and days +6 through +30 free of both announcement period returns and ex-dividend period returns. The returns from this 38 day period are used to estimate the means and standard deviations for both the announcement period SER's and the ex-dividend period SER's. If we use the same data to estimate the portfolio means and standard deviations for the announcement and ex-days, the resulting $S E R$ 's would contain common estimation errors. These errors would induce a spurious positive correlation between announcement strength and ex-dividend period $S E R$ 's. To avoid this problem, we split the 38 day period into two independent periods of equal size. We use the even days (days $-30,-28,-26$, etc.) to estimate the announcement period $S E R$ 's and the odd days (days $-29,-27,-25$, etc.) to estimate ex-dividend period $S E R$ 's.

Table 9 reports average excess returns, $S E R$ 's and $t$-statistics during the exdividend period for each of the four announcement strength quartiles. As expected, the announcement period $S E R$ 's increase monotonically from the first to the fourth quartile. Furthermore, the announcement $S E R$ 's do not sum up to zero, reflecting the positive announcement selection bias in the sample.

Table 9 shows little variation in the pattern of the ex-dividend period $S E R$ 's across quartiles. In particular, each quartile has significantly positive $S E R$ 's both before and on the ex-day. Contrary to the predictions of the announcement selection bias, the largest $S E R$ 's for days -1 and the ex-day are found in the quartile with the most negative announcement $S E R$ 's. This strengthens our conclusion that the ex-dividend period anomaly cannot be traced to the fact that our sample has a positive selection bias with respect to announcement effects. $^{23}$

\footnotetext{
${ }^{23}$ This positive selection bias will upwardly bias the estimates of $\overline{R P}$ 's. On the basis of the results in table 8 we estimate this bias to be about 0.0025 percent.
} 
Table 9

The impact of dividend announcements upon the ex-dividend period returns. The sample is all taxable distributions by common stocks on the N.Y.S.E. for the period July 2, 1962 to December 31,1980 (4,460 trading days), and is segmented by the standardized excess return for the dividend announcement period. ${ }^{\mathrm{a}}$

\begin{tabular}{|c|c|c|c|c|c|c|}
\hline \multirow[b]{2}{*}{$\begin{array}{l}\text { Trading day } \\
\text { relative to } \\
\text { ex-day }\end{array}$} & \multicolumn{3}{|c|}{$\begin{array}{l}\text { First quartile of dividend } \\
\text { announcements. The average } \\
\text { announcement period standardized } \\
\text { excess return is }-0.8213 \text {. }\end{array}$} & \multicolumn{3}{|c|}{$\begin{array}{l}\text { Second quartile of dividend } \\
\text { announcements. The average } \\
\text { announcement period standardized } \\
\text { excess return is }-0.1819 \text {. }\end{array}$} \\
\hline & $\begin{array}{l}\text { Average } \\
\text { percent } \\
\text { excess } \\
\text { return }\end{array}$ & $\begin{array}{l}\text { Average } \\
\text { standardized } \\
\text { excess } \\
\text { return }\end{array}$ & $t$-statistic & $\begin{array}{l}\text { Average } \\
\text { percent } \\
\text { excess } \\
\text { return }\end{array}$ & $\begin{array}{l}\text { Average } \\
\text { standardized } \\
\text { excess } \\
\text { return }^{c}\end{array}$ & t-statistic \\
\hline-5 & 0.0607 & 0.0319 & 1.645 & 0.0635 & 0.0449 & 2.342 \\
\hline-4 & 0.0692 & 0.0381 & 1.965 & 0.0491 & 0.0367 & 1.914 \\
\hline-3 & 0.0942 & 0.0930 & 4.796 & 0.0210 & 0.0527 & 2.749 \\
\hline-2 & 0.0979 & 0.0873 & 4.501 & 0.1319 & 0.0994 & 5.185 \\
\hline-1 & 0.2143 & 0.1885 & 9.720 & 0.1858 & 0.1582 & 8.252 \\
\hline Ex-day & 0.2080 & 0.1698 & 8.756 & 0.0792 & 0.0794 & 4.142 \\
\hline+1 & 0.0309 & 0.0208 & 1.073 & -0.0927 & -0.0553 & -2.885 \\
\hline+2 & -0.0443 & -0.0340 & -1.753 & -0.0844 & -0.0517 & -2.697 \\
\hline+3 & -0.0071 & 0.0035 & 0.180 & -0.0499 & -0.0398 & -2.076 \\
\hline+4 & 0.0327 & 0.0167 & 0.861 & -0.0114 & -0.0147 & -0.767 \\
\hline \multirow[t]{2}{*}{+5} & -0.0175 & -0.0103 & -0.581 & -0.0063 & 0.0003 & 0.016 \\
\hline & \multicolumn{3}{|c|}{$\begin{array}{l}\text { The number of ex-day portfolios } \\
\text { is } 2659 \text { and the average number } \\
\text { of stocks per portfolio is } 3.0 \text {. }\end{array}$} & \multicolumn{3}{|c|}{$\begin{array}{l}\text { The number of ex-day portfolios } \\
\text { is } 2721 \text { and the average number } \\
\text { of stocks per portfolio is } 2.9 \text {. }\end{array}$} \\
\hline & \multicolumn{3}{|c|}{$\begin{array}{l}\text { Third quartile of dividend } \\
\text { announcements. The average } \\
\text { announcement period standardized } \\
\text { excess return is } 0.2129 \text {. }\end{array}$} & \multicolumn{3}{|c|}{$\begin{array}{c}\text { Fourth quartile of dividend } \\
\text { announcements. The average } \\
\text { announcement period standardized } \\
\text { excess return is } 1.0196 \text {. }\end{array}$} \\
\hline $\begin{array}{l}\text { Trading day } \\
\text { relative to } \\
\text { ex-day }\end{array}$ & $\begin{array}{l}\text { Average } \\
\text { percent } \\
\text { excess } \\
\text { return }^{\mathrm{b}}\end{array}$ & $\begin{array}{l}\text { Average } \\
\text { standardized } \\
\text { excess } \\
\text { return }\end{array}$ & $t$-statistic & $\begin{array}{l}\text { Average } \\
\text { percent } \\
\text { excess } \\
\text { return }\end{array}$ & $\begin{array}{l}\text { Average } \\
\text { standardized } \\
\text { excess } \\
\text { return }^{\mathrm{c}}\end{array}$ & $t$-statistic \\
\hline-5 & 0.0223 & 0.0171 & 0.896 & 0.0464 & 0.0601 & 3.145 \\
\hline-4 & -0.0273 & 0.0430 & 2.254 & 0.0497 & 0.0589 & 3.082 \\
\hline-3 & 0.0519 & 0.0546 & 2.862 & 0.0487 & 0.0670 & 3.506 \\
\hline-2 & 0.0781 & 0.0827 & 4.335 & 0.0631 & 0.0650 & 3.401 \\
\hline-1 & 0.1974 & 0.1655 & 8.676 & 0.1802 & 0.1584 & 8.288 \\
\hline Ex-day & 0.0877 & 0.0946 & 4.959 & 0.0681 & 0.0705 & 3.689 \\
\hline+1 & -0.0297 & -0.0113 & -0.592 & -0.0481 & -0.0410 & -2.145 \\
\hline+2 & -0.0655 & -0.0239 & -1.253 & -0.1023 & -0.0579 & -3.030 \\
\hline+3 & -0.0011 & 0.0208 & 1.090 & 0.0078 & 0.0160 & 0.837 \\
\hline+4 & -0.0218 & -0.0214 & -1.122 & -0.0512 & -0.0264 & -1.381 \\
\hline \multirow[t]{2}{*}{+5} & -0.0714 & -0.0478 & -2.506 & -0.0761 & -0.0501 & -2.622 \\
\hline & \multicolumn{3}{|c|}{$\begin{array}{l}\text { The number of ex-day portfolios } \\
\text { is } 2748 \text { and the average number } \\
\text { of stocks per portfolio is } 2.9 \text {. }\end{array}$} & \multicolumn{3}{|c|}{$\begin{array}{l}\text { The number of ex-day portfolios } \\
\text { is } 2788 \text { and the average number } \\
\text { of stocks per portfolio is } 2.9 \text {. }\end{array}$} \\
\hline
\end{tabular}

a The announcement period standardized excess return is computed over a three day period including the dividend announcement day and one day on each side.

${ }^{b}$ Excess return equals the difference between the ex-day portfolio return on day $t$ and $\overline{R P}_{t}$ (the mean portfolio return for day $t$ estimated during the 60 day period surrounding the ex-day).

'Standardized excess return equals the excess return for the ex-day portfolio divided by the ex-day portfolio standard deviation estimated during the 60 day period surrounding the ex-day ( 30 days on each side of the ex-day). 
Table 10

The impact of non-trading upon the ex-dividend period returns. The sample is the taxable distributions by the Dow Jones 30 Industrials. Average daily excess and standardized daily excess returns of equally weighted ex-day portfolios for each day in the ex-dividend period for the period July 2, 1962 to December 31, 1980. The number of ex-dividend day portfolios is 1,226 ; the number of trading days is 4,640; and the average number of stocks in each ex-day portfolio is 1.7 .

\begin{tabular}{ccccccc}
\hline $\begin{array}{c}\text { Trading day } \\
\text { relative } \\
\text { to ex-day }\end{array}$ & $\begin{array}{c}\text { Average } \\
\text { percent } \\
\text { excess } \\
\text { return }^{\mathbf{a}}\end{array}$ & $\begin{array}{c}\text { Average } \\
\text { standardized } \\
\text { excess } \\
\text { return }^{\mathbf{b}}\end{array}$ & t-statistic & $\begin{array}{c}\text { Significance } \\
\text { level }\end{array}$ & \multicolumn{2}{c}{\begin{tabular}{c} 
Posterior odds ratios \\
\cline { 5 - 6 }
\end{tabular}} \\
\hline-5 & -0.0560 & -0.0295 & -1.033 & 0.3016 & 16.387 & 1.033 \\
-4 & 0.0259 & 0.0287 & 1.005 & 0.3140 & 16.860 & 1.063 \\
-3 & 0.0432 & 0.0533 & 1.866 & 0.0620 & 4.896 & 0.3087 \\
-2 & 0.0935 & 0.0834 & 2.920 & 0.0034 & 0.3931 & 0.0248 \\
-1 & 0.2984 & 0.2289 & 8.015 & $<10^{-4}$ & $<10^{-4}$ & $<10^{-4}$ \\
Ex-day & 0.1856 & 0.1520 & 5.322 & $<10-4$ & $<10^{-4}$ & $<10^{-4}$ \\
+1 & -0.1596 & -0.1169 & -4.093 & $<10-4$ & 0.0064 & 0.0004 \\
+2 & -0.0788 & -0.0622 & -2.178 & 0.0294 & 2.607 & 0.1644 \\
+3 & -0.1239 & -0.0969 & -3.393 & 0.0006 & 0.0884 & 0.0056 \\
+4 & -0.0254 & -0.0342 & -1.197 & 0.2312 & 13.640 & 0.8598 \\
+5 & -0.0571 & -0.0559 & -1.957 & 0.0504 & 4.114 & 0.2594 \\
\hline
\end{tabular}

${ }^{a}$ Excess return equals the difference between the ex-day portfolio return on day $t$ and $\overline{R P}_{t}$ (the mean portfolio return for day $t$ estimated during the 60 day period surrounding the ex-day).

${ }^{b}$ Standardized excess return equals the excess return for the ex-day portfolio divided by the ex-day portfolio standard deviation estimated during the 60 day period surrounding the ex-day ( 30 days on each side of the ex-day).

${ }^{c}$ Both cases assume that the null hypothesis of no tax premium is true with probability 0.5 . The prior beliefs about the alternative hypotheses are represented as a 0.5 probability that (1) the mean ex-day $S E R$ is between -1 and +1 with uniform probability, and (2) the mean $S E R$ is distributed as normal with a mean of zero and a standard deviation of 0.316 .

\subsection{The non-trading effect}

Part of the surrounding day results may be due to non-trading of securities. The prices that are recorded as closing prices are either the last trade price of the day or a bid-ask average and may not be the 'true' end of the day price. The exact impact of this on our results is difficult to pinpoint. However, it is easy to imagine that tax trading induces heavier volume and therefore more multiple day returns before ex-days or that actions of the specialist impart a pattern to the returns surrounding ex-days. ${ }^{24}$ There is a simple and obvious way of investigating the influence of non-trading; examining the behavior of a sample of heavily traded securities: the Dow Jones 30 Industrial stocks.

\footnotetext{
${ }^{24}$ Black and Scholes (1973) offer a scenario on how the behavior of the specialist on a non-traded security on the ex-day may bias the ex-day returns upward and the post ex-day returns downward. Specifically, they argue that if the specialist fails to adjust the price of a non-traded security on its ex-day, the ex-day return will be biased upward by the amount of the dividend. When the security does trade after the ex-day, the result will be a downward biased return on that day.
} 
We compute the SER's for five days on each side of the ex-day for the Dow Jones 30 Industrial stocks during the period of July 2, 1962 through December 31, 1980. According to the non-trading explanations, the ex-dividend period anomaly should be non-existent for the Dow or, at least, substantially less than that reported in table 5 (the taxable distributions by common stocks).

Table 10 reports the ex-dividend period results for the Dow Jones 30 . In contrast to the non-trading explanation, the securities in the Dow Jones 30 exhibit ex-dividend period excess returns and $S E R$ 's which are similar to those reported in table 5 . Thus, the ex-dividend period anomaly documented in section 3 appears to be independent of the trading frequency of the securities. ${ }^{25}$

\subsection{The normality assumption}

Finally, we examine the sensitivity of our results to the assumption that security returns are distributed as multivariate normal. The Wilcoxon matched-pair rank-sum test is run for each of our samples during the exdividend period. This test requires that the observations be independently drawn from a continuous distribution, but makes no other assumptions concerning the underlying excess return distribution. It also has low power relative to the null hypothesis of zero excess returns. ${ }^{26}$

Table 11 reports the $z$-statistics and the asymptotic significance levels of the rank-sum test. In spite of the low power of the test, the results of table 11 are consistent with the $t$-values reported earlier in tables 5, 6, 7, and 10 . With the exception of the stock dividends and splits sample, each of the samples exhibit anomalous pricing behavior for at least the four day period from day -1 through day +2 . These results suggest that we cannot attribute the statistical significance of the anomaly to a violation of the normality assumption. ${ }^{27}$

\footnotetext{
${ }^{25}$ Along similar lines, we examine the volume of the Dow Jones 30 around their ex days. We estimate the following model for the daily volume of the securities included in the Dow:

$$
\begin{aligned}
\ln V_{i, t}= & \alpha_{i, 0}+\alpha_{i, 1} \ln V_{i, t, 1}+\alpha_{i, 2} \ln V_{i, l-2}+\alpha_{i, 3} \ln V_{i, t-3}+\alpha_{i, M 2} D M 2_{i, 1} \\
& +\alpha_{i, M 1} D M 1_{i, t}-\alpha_{i, x} D X_{i, t}+\alpha_{i, P 1} D P 1_{i, t}+\alpha_{i, P 2} D P 2_{i, t}+\tilde{\varepsilon}_{i, t} .
\end{aligned}
$$$$
i=1,2, \ldots, 30, \quad t=1,2, \ldots, t \text {, }
$$

where In indicates the natural $\log , V_{i, l}$ is the volume of security $i$ on day $t, D M 2_{i, t}, D M 1_{,, t}, D X_{i, t}$, $D P 1_{i, l}$, and $D P 2_{t, l}$ are dummy variables corresponding to the five day period surrounding the ex-day, i.e., $D M 2$ equals one on day -2 and zero otherwise, $D M 1$ is one on day -1 and zero otherwise, $D X$ is the ex-day dummy, etc. The idea of this model is to detect unusual trading volume with the dummy variables $D M 2, D M 1, D X, D P 1$, and $D P 2$.

The model is estimated separately for each of the thirty securities included in the Dow Jones 30 . The data used in this estimation was made available to us by Compuserve for the period January 1 , 1974 to December 31,1981 . This investigation reveals no apparent pattern in the trading volume coefficient (i.e., the dummy variable coefficients). The results are consistent with our conclusion that non-trading is not a viable explanation of the ex-dividend anomaly.

${ }^{26}$ See Kendall and Stuart (1979, pp. 520-521) for a discussion of the rank-sum test and its distributional properties.

${ }^{27}$ These tests were also run using $R P_{i}$ 's which were calculated excluding every day of the ex-dividend period. The results were not qualitatively different from those in table 11.
} 


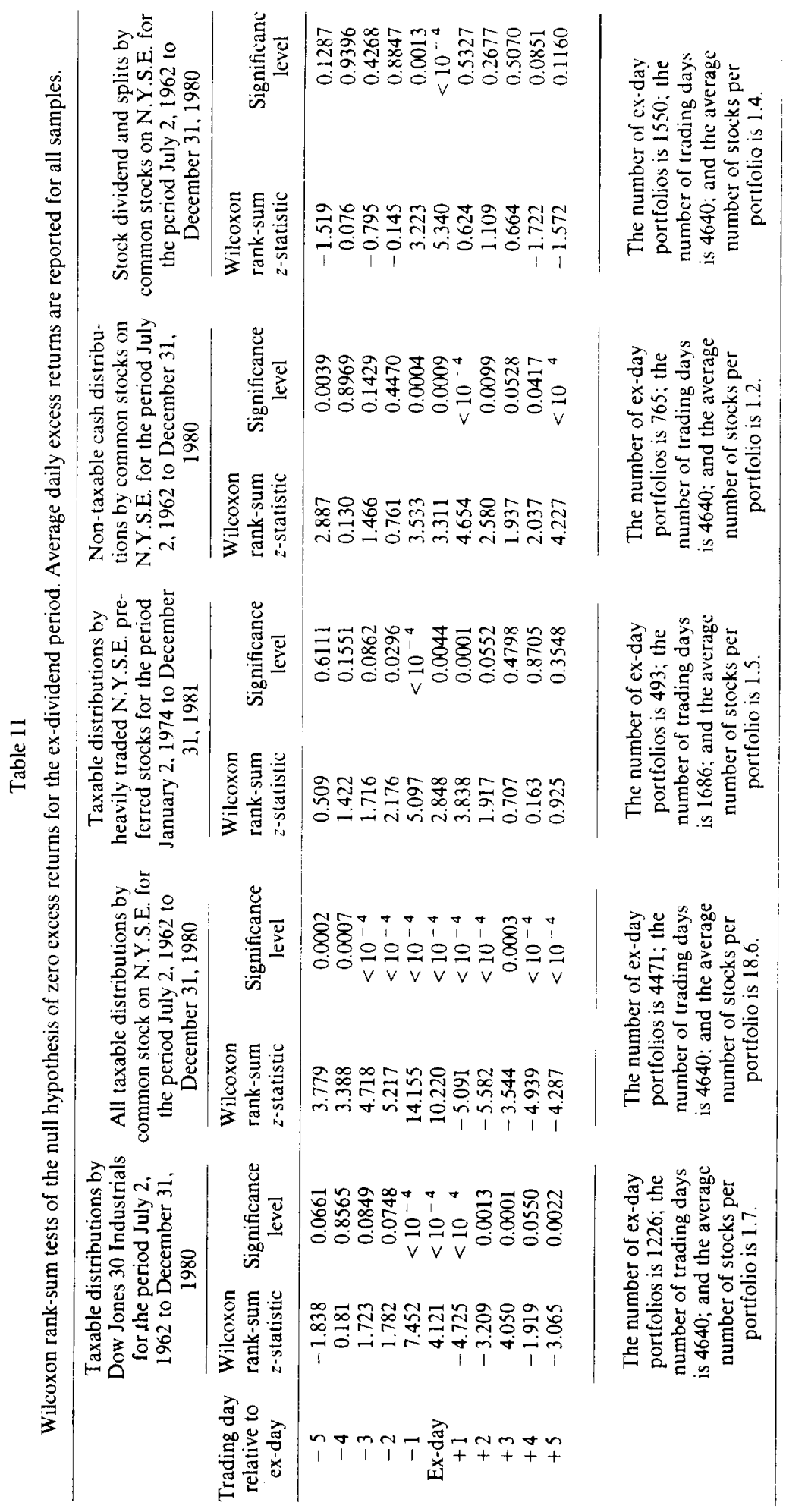




\section{Conclusions}

The results of this study suggest that the excess returns on ex-dividend days cannot be completely explained by the tax hypothesis that dividends are taxed more heavily than capital gains in the U.S. Tax Code. The results also suggest that one cannot infer differential tax rates between dividends and capital gains from the average relative price drop on the ex-dividend day.

The ex-day results for the taxable common stock distributions are consistent with the tax interpretation. The excess returns are positive, they are realized on the opening trade of the ex-day, and they appear to be directly related to the costs of transacting on the N.Y.S.E. However, for our sample of taxable preferred stock dividends, we find significantly negative excess returns on the ex-day, and these returns do not diminish with the introduction of negotiated commissions. Although this result is not consistent with the tax hypothesis in its simplest form, the negative premium may be explained by the tax-induced dividend clienteles. For example, the marginal purchasers of preferred stocks may be corporations that are subject to lower tax rates on dividends than on capital gains. ${ }^{28}$

When we examine ex-day returns for stock dividends and splits and nontaxable cash distributions, the results are quite surprising. The ex-day excess returns for non-taxable stock dividends and splits are significantly positive, while the ex-day excess returns for non-taxable cash distributions are significantly negative. These results are not consistent with either the simple form of the tax hypothesis or tax-induced dividend clienteles.

The behavior of returns surrounding ex-days casts further doubt upon the tax hypothesis. The analysis of the ex-dividend period reveals that the ex-day returns are not unique relative to those of the ten surrounding days. An interesting manifestation of this is the day before the ex-day. We find that this day has a significantly positive excess return which, with the exception of the stock dividends and splits, is larger than the average ex-day excess return. On balance, this result suggests that the ex-day returns are part of a larger ex-dividend period anomaly, and we find ourselves with a large set of puzzling results in search of a new interpretation.

Although we have considered several alternative explanations, none appears to be viable. A closer examination of our data indicates that virtually no recording errors for the ex-dividend dates are present, nor do we find the day of the week effect to be a likely cause for the anomalous results. We also examine the possibility that dividend announcements have contaminated our experimental design. Although our sampling procedure is biased toward positive announcement effects, this bias does not provide an adequate explanation

\footnotetext{
${ }^{28}$ These results might be interpreted as a possible motivation for issuance of preferred stocks by corporations in spite of the fact that they are similar to debt instruments without the tax benefits: when a firm is issuing preferred stocks instead of long-term debt, it is foregoing the corporate interest tax shields for the benefits of the lower pre-tax cost of capital.
} 
for the anomaly. In particular, neither the proximity of the announcement and the ex-day nor the strength of the announcement are able to completely explain the anomalous pricing behavior. Because the ex-dividend period anomaly exists even for the frequently traded securities included in the Dow Jones Industrials, we also reject non-trading as an explanation. Finally, we document the anomaly with a non-parametric test, and conclude that the ex-dividend period anomaly is not sensitive to our statistical assumptions.

In conclusion, we cannot offer a rational explanation of our results; therefore, we submit that ex-dividend period returns remain an anomaly. ${ }^{29}$ On a more positive note, we have been successful in eliminating several plausible conjectures and common misconceptions from the list of possible explanations. Hopefully, the task of future researchers has been significantly reduced.

\section{References}

Aharoney, J. and I. Swary, 1980, Quarterly dividend and earnings announcements and stockholder's returns: An empirical analysis, Journal of Finance 35, 1-12.

Black, F. and M. Scholes, 1973, The behavior of security returns around ex-dividend days, Unpublished paper (University of Chicago, Chicago, IL).

Black, F. and M. Scholes, 1974. The effects of dividend yield and dividend policy on common stock prices and returns, Journal of Financial Economics 1, 1-22.

Campbell, J. and W. Beranek, 1955, Stock price behavior on ex-dividend dates, Journal of Finance $10,425-429$.

Charest, G., 1978, Dividend information, stock returns, and market efficiency - II, Journal of Financial Economics 6, 297-330.

Durand, D. and A.M. May, 1960, The ex-dividend behavior of American Telephone and Telegraph stocks, Journal of Finance 15, 19--31.

Elton, E. and M. Gruber, 1970, Marginal stockholders tax rates and the clientele effect, Review of Economics and Statistics 52, 68-74.

Fama, E., L. Fisher, M. Jensen and R. Roll, 1969, The adjustment of stock prices to new information, International Economic Review 10, 1-21.

French, K., 1980, Stock returns and the weekend effect, Journal of Financial Economics 8, 55-70.

Gibbons, M. and P. Iless, 1981, Day of the week effects and asset returns, Journal of Business 54, $579-597$.

Hess, P., 1982, The ex-dividend day behavior of stock returns: Further evidence on tax effects, Journal of Finance $37,445-456$.

Hess, P., 1983, Test for tax effects in the pricing of financial assets, Journal of Business, forthcoming.

Kalay, A., 1982, The ex-dividend day behavior of stock prices: A re-examination of the clientele effect, Journal of Finance 37, 1059-1070.

Kendall, M. and A. Stuart, 1979, The advanced theory of statistics, Vol. 2 (MacMillan, New York).

Litzenberger, R. and K. Ramaswamy, 1979, The effect of personal taxes and dividends on capital asset prices: theory and empirical evidence, Journal of Financial Economics 7, 163-195.

Litzenberger, R. and K. Ramaswamy, 1980, Dividends, short selling restrictions, tax induced investor clientele and market equilibrium, Journal of Finance 35, 469-482.

Long. J.B., 1978, The market valuation of cash dividends: A case to consider, Journal of Financial Economics 6, 235-264.

\footnotetext{
${ }^{29}$ Another obvious, but untestable explanation is that markets are sloppy in accounting for the ex-day tax effect and spread it over several days. Like most market incfficicncy explanations, this explanation has no empirical content.
} 
Miller, M. and M. Scholes, 1982, Dividends and taxes: Empirical evidence, Journal of Political Economy 90, 1118-1141.

Pettit, R., 1972, Dividend announcements, security performance, and capital market efficiency, Journal of Finance 27, 993-1007.

Phillips, S. and C. Smith, 1980, Trading costs for listed options: The implications for market efficiency, Journal of Financial Economics 8, 179-199.

Zellner, A., 1971, An introduction to Bayesian inference in econometrics (Wiley, New York). 